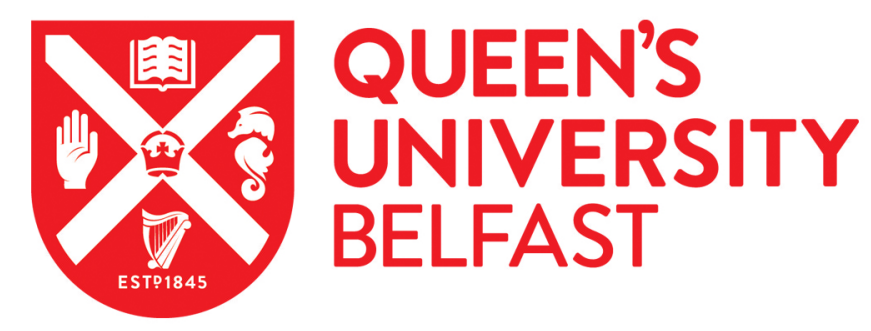

\title{
Lighting-up Protein-Ligand Interactions with Fluorescent PET (Photoinduced Electron Transfer) Sensor Designs
}

McLaughlin, B., de Silva, A. P., Wright, G. D., Daly, B., \& Surender, E. M. (2017). Lighting-up Protein-Ligand Interactions with Fluorescent PET (Photoinduced Electron Transfer) Sensor Designs. Chemical Communications, 54, 1319. https://doi.org/10.1039/C7CC05929A

Published in:

Chemical Communications

Document Version:

Peer reviewed version

Queen's University Belfast - Research Portal:

Link to publication record in Queen's University Belfast Research Portal

Publisher rights

(C) 2017 Royal Society of Chemistry.

This work is made available online in accordance with the publisher's policies. Please refer to any applicable terms of use of the publisher.

\section{General rights}

Copyright for the publications made accessible via the Queen's University Belfast Research Portal is retained by the author(s) and / or other copyright owners and it is a condition of accessing these publications that users recognise and abide by the legal requirements associated with these rights.

Take down policy

The Research Portal is Queen's institutional repository that provides access to Queen's research output. Every effort has been made to ensure that content in the Research Portal does not infringe any person's rights, or applicable UK laws. If you discover content in the Research Portal that you believe breaches copyright or violates any law, please contact openaccess@qub.ac.uk. 


\section{Lighting-up Protein-Ligand Interactions with Fluorescent PET (Photoinduced Electron Transfer) Sensor Designs ${ }^{\ddagger}$}

Bernard McLaughlin, ${ }^{a}$ Esther M. Surender, ${ }^{a}$ Glenn D. Wright, ${ }^{a}$ Brian Daly and A. Prasanna de Silva ${ }^{a}$

THE FLUORESCENCE OF SENSORS 1 AND 6, WHICH ARE DESIGNED IN TERMS OF PHOTOINDUCED ELECTRON TRANSFER (PET), ARE SWITCHED 'ON' BY FACTORS OF 15 AND 6 WITH AVIDIN IN A RATHER SELECTIVE MANNER. 3 AND 7, SIMPLER DERIVATIVES OF 1, ARE SWITCHED 'ON’ BY FACTORS OF 16 AND 7.5 WITH BOVINE SERUM ALBUMIN, THOUGH AT 30-FOLD HIGHER CONCENTRATIONS.

The fluorescent PET sensing/switching design ${ }^{1}$ is a useful tool for over 350 laboratories. ${ }^{2}$ The major class of sensors has exploited metal ion coordination. ${ }^{3}$ Another important class of fluorescent sensors designed in terms of PET has used reversible covalent bonding involving saccharides, ${ }^{4}$ even though the detailed mechanism is under discussion. ${ }^{5}$ Another class of PET fluorescent reagents/chemdosimeters involves irreversible covalent bonding. ${ }^{6}$ PET-based designs also sense membrane potential, ${ }^{7}$ environmental polarity ${ }^{8,9}$ and enzymes. ${ }^{10}$ We now demonstrate that rather specific receptor proteins and non-specific transport proteins ${ }^{9}$ can be exploited within the fluorescent PET sensing design, as exemplified by avidin and bovine serum albumin (BSA) respectively.

Since the avidin-biotin interaction is the basis of several technologies, ${ }^{11}$ and since biotin enters a $\beta$-barrel of the protein to isolate the entrant from bulk water, ${ }^{12}$ this protein-ligand interaction was attractive to apply the fluorescent PET sensor/switch design. Though the dimethoxybenzylanthracene unit cannot enter the $\beta$ - barrel, its location in the water adjacent to the protein surface would be rather apolar, as evidenced by reduced $\mathrm{H}^{+}$densities in related locations in waterorganic interfaces for instance. ${ }^{13}$ We and others ${ }^{8,9}$ had demonstrated that apolar environments can cause strong switching 'on' of fluorescence by retarding the competing charge-separating PET process. Fine examples of selective 'off-on' fluorescent biotin-based sensors have been designed for avidin on the basis of polarity-sensitive ICT (internal charge transfer) excited states (one of which involves a separate PET process involving a thiol reaction), ${ }^{14}$ torsionally-restricted thiazole orange derivatives ${ }^{15}$ and disaggregation. ${ }^{16}$ There is a pseudointramolecular PET pair which dissociates upon engulfment of one partner by avidin so that the PET process ceases. ${ }^{17} \mathrm{~A}$ carbon nanotube is essential for this nanotechnology application and a small-molecule fluorophore with a tiny $\pi$-surface cannot be expected to undergo the necessary adsorption process. This is quite different from our case where the small-molecule PET pair is covalently linked and the PET rate is retarded by reducing the polarity of the environment by avidin since several PET pairs, e.g. anthracene-amine, anthracenealkoxybenzene, anthracene-benzocrown ether, BODIPY-benzocrown ether, azaBODIPY-amine, have been shown to have polarity-dependent fluorescence. ${ }^{8,9}$ Though noncovalently-assembled PET and related systems ${ }^{17,18}$ have advantages of easier synthesis and combinatorial options, they are prone to the crucial weakness of disassembling in uncontrolled multicompartmental nanoenvironments (e.g. cells) and incorporating the components differentially into various compartments so that the fluorescence signal becomes indecipherable. In contrast, covalently linked PET systems ${ }^{19}$ have a history of successful operation in complex environments, and offer good prospects for cases like 1.

PET between suitable anthracenes and $o$-dialkoxybenzenes is known in intermolecular situation $5^{20}$ and has been exploited in several intramolecular contexts. ${ }^{21-23}$ Sensor $\mathbf{1}$ arose from such thinking. It was synthesized from $\mathbf{2}^{23}$ by reaction with $\mathbf{4}$, the product of biotin coupled with $\mathrm{N}, \mathrm{N}$-diethylethylenediamine (DCC, see ESI).

It is clear from Fig. 1 that the fluorescence of $\mathbf{1}$ in water switches 'on' substantially upon encountering avidin at sub- $\mu \mathrm{M}$ concentrations, while preserving other parameters of the spectrum as is usually found in fluorescent PET systems. ${ }^{24}$ Similar concentrations of concanavalin A and BSA elicit smaller responses (Fig. 2). Derivative 3, which lacks the biotin moiety, produces a negligible fluorescence response from avidin under similar conditions (Fig. 2). These control experiments suggest that the hydrophobicity of dimethoxybenzylanthracene moiety of $\mathbf{1}$ or $\mathbf{3}$ is not sufficient to cause a significant degree of nonspecific association with apolar patches on the avidin surface. A further deduction from these experiments is that any nonspecific protein-induced disaggregation is not significantly responsible for the avidin-induced fluorescence switching 'on', a point relevant to the role of disaggregation in the fluorescence enhancements found in sensors for sugars based on PET designs. ${ }^{4,5}$

The $\log \beta$ value of 5.1 measured for the interaction of 1 with avidin is in the range of those found for various biotin derivatives. In contrast, the massive $\log \beta$ value of 15 found when underivatized biotin is bound inside the $\beta$-barrel is due to a peptide loop closing off the ligand for a tight fit. ${ }^{11,12}$ As a step towards demonstrating the generality of our approach, we find that 6, which employs the anthracene-benzocrown ether PET pair, produces a fluorescence intensity enhancement factor of 6.1 when presented with $20 \mu \mathrm{M}$ avidin (see ESI, section S2 and Fig. 4a). 
The structurally simpler $\mathbf{3}$ is subjected to a detailed study of its polarity-sensitive fluorescence. It was prepared by a procedure analogous to that of $\mathbf{1}$ (see ESI). The solvent-dependent quantum yield $\left(\phi_{F}\right)$ data are reasonably fitted to theory 8,25 (Fig. 3 inset). This is consistent with a polarity-dependent process, such as a charge-separating PET pathway, being competitive against fluorescence emission for deactivation of the excited state.

The fluorescence response of $\mathbf{3}$ to the transporter protein BSA is shown in Figs. S1 and 3. The switching 'on' of fluorescence is attributed to retardation of PET by binding of $\mathbf{3}$ to a site in BSA. In contrast, previous fluorescence 'off-on' sensors for BSA are dominated by TICT (twisted intramolecular charge transfer) excited states, ${ }^{26}$ except for a solitary example which is based on a fluorescent PET sensing design. ${ }^{9} \mathbf{3}$ appears to bind non-selectively but similarly to the warfarin- and ibuprofen-binding sites of BSA according to drug-induced fluorescence quenching factors of 1.13 and 1.23 respectively (140 $\mu \mathrm{M}$ drug). Further support for the generality of our approach is found in benzocrown ether 7, which responds to $1.2 \mathrm{mM}$ BSA with a FE value of 7.5 (see ESI, section S2 and Fig. 4b). This FE value and that of 6 due to Avidin are lower than those seen for the dimethoxybenzene versions $\mathbf{1}$ and $\mathbf{3}$ because the former cases are less hydrophobic and place their PET pair at an average position further from the protein surface where the polarity is higher, and hence PET is faster. Similar hydrophobic tuning of probe positions near membranes are known. ${ }^{13}$ Sensors $\mathbf{6}$ and $\mathbf{7}$ also show the extendability of our approach since they could allow measurement of metal ions in nanospaces adjacent to protein surfaces (as done in membrane-bounded nanospaces ${ }^{22}$ ) near the active site. These double-input systems ${ }^{27}$ share conceptual similarities with photoaffinity labels. ${ }^{28} \mathrm{Na}^{+}$binding in the benzocrown causes further suppression of $\mathrm{PET}^{3}$ but the reduced hydrophobicity shifts the PET pair to a position of higher polarity ${ }^{13}$ which accelerates PET. ${ }^{9}$ The nett effect on fluorescence depends on the nature of the protein (Fig. 4) and the sidechains of the amino acid residues neighbouring the charged units of the sensors.

We conclude that the fluorescent PET sensing/switching approach is a design platform for targeting proteins as illustrated by $\mathbf{1}$ and $\mathbf{6}$ for avidin and by $\mathbf{3}$ and $\mathbf{7}$ for BSA. Detailed evaluation of the mechanism will require laser photolysis studies to observe the presence (or not) of radical ion intermediates ${ }^{29}$ which are outside the scope of this work. Nevertheless, using a ligand to carry a covalently linked fluorescent PET pair into a protein location extends the reach of fluorescent PET sensing/switching systems.

We acknowledge the Department of Employment and Learning, Northern Ireland and T. J. Lively for support.

\section{Notes and references}

¥ In memoriam Professor Tony McKervey

1 Y. C. Wang and H. Morawetz, J. Am. Chem. Soc. 1976, 98, 3611; B. K. Selinger, Aust, J. Chem. 1977, 30, $2087 ;$ G. S. Beddard, R. S. Davidson and T. D. Whelan, Chem. Phys. Lett. 1978, 56, 54; H. Shizuka, M. Nakamura and T. Morita, J. Phys. Chem. 1979, 83, 2019; H. Shizuka, T. Ogiwara and E. Kimura, J. Phys. Chem. 1985, 89, 4302; J. P. Konopelski, F. Kotzyba-Hibert, J. -M. Lehn, J. -P. Desvergne, F. Fages, A. Castellan and H. Bouas-Laurent, J. Chem. Soc., Chem. Commun. 1985, 433; A. P. de Silva and R. A. D. D. Rupasinghe, J. Chem. Soc. Chem. Commun. 1985, 1669; G. Grynkiewicz, M. Poenie and R. Y. Tsien, J. Biol. Chem. 1985, 206, 3440; A. P. de Silva and S. A. de Silva, J. Chem. Soc. Chem. Commun. 1986, 1709; M. E. Huston, K. W. Haider and A. W. Czarnik, J. Am. Chem. Soc. 1988, 110, 4460; A. J. Bryan, A. P. de Silva, S. A. de Silva, R. A. D. D. Rupasinghe and K. R. A. S. Sandanayake, Biosensors 1989, 4, 169; A. P. de Silva, S. A. de Silva, A. S. Dissanayake and K. R. A. S. Sandanayake, J. Chem. Soc. Chem. Commun. 1989, 1054; A. P. de Silva and K. R. A. S. Sandanayake, J. Chem. Soc. Chem. Commun. 1989, 1183; A. P. de Silva and H. Q. N. Gunaratne, J. Chem. Soc. Chem. Commun. 1990, 186; A. P. de Silva, H. Q. N. Gunaratne and K. R. A. S. Sandanayake, Tetrahedron Lett. 1990, 31, 5193; A. P. de Silva and K. R. A. S. Sandanayake, Angew. Chem. Int. Ed. Engl. 1990, 29, 1173; E. U. Akkaya, M. E. Huston and A. W. Czarnik, J. Am. Chem. Soc. 1990, 112, 3590; R. A. Bissell and A. P. de Silva, J. Chem. Soc. Chem. Commun. 1991, 1148.

2 B. Daly, J. Ling and A. P. de Silva, Chem. Soc. Rev. 2015, 44, 4203; A. P. de Silva, H. Q. N. Gunaratne, T. Gunnlaugsson, A. J. M. Huxley, C. P. McCoy, J. T. Rademacher and T.E. Rice, Chem. Rev. 1997, 97, 1515; A. P. de Silva, T. S. Moody and G. D. Wright, Analyst 2009, 134, 2385; Chemosensors (Eds: B. H. Wang and E. V. Anslyn) Wiley, Hoboken, 2011; A. P. Demchenko, Introduction to Fluorescence Sensing $2^{\text {nd }}$ Ed, Springer, Heidelberg, 2015.

33 L. Dong, Y. Zang, D. Zhou, X. P. He, G. R. Chen, T. D. James and J. Li, Chem. Commun. 2015, 51, 11852; T. Schwarze, R. Schneider, J. Riemer and H. -J. Holdt, Chem. Asian J. 2016, 11, 241; T. Schwarze, H. Mueller, D. Schmidt, J. Riemer and H. -J. Holdt, Chem. Eur. J. 2017, 23, 7255; S. Chithiraikumar, C. Balakrishnan and M. A. Neelakantan, Sens. Actuat. B Chem. 2017, 249, 235; N. I. Georgiev, M. D. Dimitrova, A. Ts. Mavrova and V. B. Bojinov, Spectrochim. Acta A, Mol. Biomol. Spectrosc. 2017, 183, 7; A. V. Saura, M. I. Burguete, F. Galindo and S. V. Luis, Org. Biomol. Chem. 2017, 15, 3013; www.optimedical.com; www.idexx.com.

4 T. D. James, K. R. A. S. Sandanayake and S. Shinkai, J. Chem. Soc. Chem. Commun. 1994, 477; T. D. James, K. R. A. S. Sandanayake and S. Shinkai, Angew. Chem. Int. Ed. Engl. 1994, 33, 2207;T. D. James, K. R. A. S. Sandanayake and S. Shinkai, Nature 1995, 374, 345; T. D. James, K. R. A. S. Sandanayake, R. Iguchi and S. Shinkai, J. Am. Chem. Soc. 1995, 117, 8982; T. D. James, K. R. A. S. Sandanayake and S. Shinkai, Angew. Chem. Int. Ed. Engl. 1996, 35, 
1910; J. Z. Zhao and T. D. James, Chem. Commun. 2005, 1889; X. L. Sun and T. D. James, Chem. Rev. 2015, 115, 8001; B. Rout, L. Unger, G. Armony, M. A. Iron and D. Margulies, Angew. Chem. Int. Ed. 2012, 124, 12645; B. Rout, L. Motiei and D. Margulies, Synlett 2014, 25, 1050; B. Rout, P. Milko, M. A. Iron, L. Motiei and D. Margulies, J. Am. Chem. Soc., 2013, 135, 15330; www.glysure.com.

5 B. M. Chapin, P. Metola, S. L. Vankayala, H. L. Woodcock, T. J. Mooibroek, V. M. Lynch, J. D. Larkin and E. V. Anslyn, J. Am. Chem. Soc. 2017, 139, 5568.

6 J. K. Weltman, R. P. Szaro, A. R. Frackelston, R. M. Dowben, J. R. Bunting, R. E. Cathou, J. Biol. Chem. 1973, 218, 3173; Y. Kanaoka, Angew. Chem. Int. Ed. Engl. 1977, 16, 137; A. Russo and E. A. Bump, Meth. Biochem. Anal. 1988, 33, 165; H. J. Verhey, C. H. W. Bekker, J. W. Verhoeven and J. W. Hofstraat, New J. Chem. 1996, 20, 809; A. P. de Silva, H. Q. N. Gunaratne and T. Gunnlaugsson, Tetrahedron Lett. 1998, 39, 5077; S. P. Levine, J. H. Hoggatt, E. Chladek, G. Jungclaus and J. L. Gerlock, Anal. Chem. 1979, 51, 1106; C. Sangoe and E. Zimerson, J. Liq. Chromatogr. 1980, 3, 971; H. Kojima and T. Nagano, Adv. Mater. 2000, 12, 763; Y. Gabe, T. Ueno, Tasuku, Y. Urano, H. Kojima and T. Nagano, Anal. Bioanal. Chem. 2006, 386, 621; M. Onoda, S. Uchiyama, A. Endo, H. Tokuyama, T. Santa and K. Imai, Org. Lett. 2003, 5, 1459; M. Onoda, S. Uchiyama, T. Santa and K. Imai, Anal. Chem. 2002, 74, 4089.

7 E. W. Miller, J. Y. Lin, E. P. Frady, P. A. Steinbach, W. B. Kristan and R. Y. Tsien, Proc. Natl. Acad. Sci. USA 2012, 109, 2114; C. R. Woodford, E. P. Frady, R. S. Smith, B. Morey, G. Canzi, S. F. Palida, R. C. Araneda, W. B. Kristan, C. P. Kubiak, E. W. Miller and R. Y. Tsien, J. Am. Chem. Soc. 2015, 137, 1817; V. Grenier, A. S. Walker, and E. W. Miller, J. Am. Chem. Soc. 2015, 137, 10894; P. E. Deal, R. U. Kulkarni, S. H. Al-Abdullatif, and E. W. Miller, J. Am. Chem. Soc. 2016, 138, 9085; E. W. Miller, Curr. Opin. Chem. Biol. 2016, 33, 74; R. U. Kulkarni, H. Yin, N. Pourmandi, F. James, M. M. Adil, D. V. Schaffer, Y. Wang and E. W. Miller, ACS Chem. Biol. 2017, 12, 407; R. U. Kulkarni, D. J. Kramer, N. Pourmandi, K. Karbasi, H. S. Bateup and E. W. Miller, Proc. Natl. Acad. Sci. USA 2017, 114, 2813.

8 A. P. de Silva and K. R. A. S. Sandanayake, Tetrahedron Lett. 1991, 32, 421; R. A. Bissell, A. P. de Silva, W. T. M. L. Fernando, S. T. Patuwathavithana and T. K. S. D. Samarasinghe, Tetrahedron Lett. 1991, 32, 425; K. Rurack, M. Kollmannsberger, U. Resch-Genger, W. Rettig and J. Daub, Chem. Phys. Lett. 2000, 329, 363; J. F. Callan, A. P. de Silva, D. B. Fox, N. D. McClenaghan and K. R. A. S. Sandanayake, J. Fluoresc. 2005, 15, 769; M. J. Hall, L. T. Allen and D. F. O'Shea, Org. Biomol. Chem. 2006, 4, 776.

9 H. Sunahara, Y. Urano, H. Kojima and T. Nagano, J. Am. Chem. Soc. 2007, 129, 5597.

10 W. Zhang, Z. Ma, L. P. Du and M. Y. Li, Analyst, 2014, 139, 2641; T. Guo, L. Cui, J. N. Shen, W. P. Zhu, Y. F. Xu and X. H. Qian, Chem. Commun. 2013, 49, 10820; D. D. Li, Y. Q. Xu, N. N. Zhou, J. X. Liu, R. Wang, T. Cheng, Y. Tang, W. P. Zhu, Y. F. Xu and X. H. Qian, Dyes Pigm. 2017, 136, 627; X. Ao, S. A. Bright, N. C. Taylor and R. B. P. Elmes, Org. Biomol. Chem. 2017, DOI: 10.1039/C7OB01406F.

11 Avidin-Biotin Interactions, Ed. R. J. McMahon, Humana Press, Totowa, NJ, 2010.

12 O. Livnah, E. A. Bayer, M. Wilchek and J. L. Sussman, Proc. Nat. Acad. Sci. USA, 1993, 90, 5076; M. Wilchek, E. A. Bayer and O. Livnah, Immunol. Lett. 2006, 103, 27.

13 S. Uchiyama, K. Iwai and A. P. de Silva, Angew. Chem. Int. Ed. Engl. 2008, 47, 4667; R. A. Bissell, A. J. Bryan, A. P. de Silva and C. P. McCoy, J. Chem. Soc. Chem. Commun. 1994, 405; P. Ball, Chem. Rev. 2008, 108, 74.

14 Q. Sun, J. H. Qian, H. Y. Tian, L. P. Duan and W. B. Zhang, Chem. Commun. 2014, 50, 8518; Q. Sun, H. Y. Tian, H. R. Qu, D. H. Sun, Z. Chen, L. P. Duan, W. B. Zhang and J. H. Qian, Analyst, 2015, 140, 4648; Q. Sun, D. H. Sun, L. Song, Z. Chen, Z. Y. Chen, W. B. Zhang and J. H. Qian, Anal. Chem. 2016, 88, 3400.

15 L. Unger-Angel, B. Rout, T. Ilani, M. Eisenstein, L. Motiei and D. Margulies, Chem. Sci. 2015, 6, 5419.

16 Q. Y. He, X. P. Fan, S. G. Sun, H. J. Li, Y. X. Pei and Y. Q. Xu, RSC Adv. 2015, 5, 38571.

17 B. C. Satishkumar, L. O. Brown, Y. Gao, C. -C. Wang, H. -L. Wang and S. K. Doorn, Nat. Nanotechnol. $2007,2,560$.

18 A. P. de Silva, C. M. Dobbin, T. P. Vance and B. Wannalerse, Chem. Commun. 2009, 1386; B. T. Nguyen and E. V. Anslyn, Coord. Chem. Rev. 2006, 250, 3118; Y. Diaz-Fernandez, F. Foti, C. Mangano, P. Pallavicini, S. Patroni, A. Gramatges and S. Rodriguez-Calvo, Chem. Eur. J. 2006, 12, 921.

19 A. Minta, J. P. Y. Kao and R. Y. Tsien, J. Biol. Chem. 1989, 264, 8171; S. Uchiyama, G. D. McClean, K. Iwai and A. P. de Silva, J. Am. Chem. Soc. 2005, 127, 8920.

20 J. Eriksen and C. S. Foote, J. Phys. Chem. 1978, 82, 2659.

21 A. P. de Silva and K. R. A. S. Sandanayake, J. Chem. Soc. Chem. Commun. 1989, 1183; A. Torrado and B. Imperiali, J. Org. Chem. 1996, 61, 8940; H. F. Ji, R. Dabestani and G. M. Brown, J. Chem. Soc. Perkin Trans. 2, 2002, 636; H. Xu, X. H. Xu, R. Dabestani. G. M. Brown, L. Fan and H. F. Ji, J. Am. Chem. Soc. 2000, 122, 9306.

22 S. Uchiyama, E. Fukatsu, G. D. McClean and A. P. de Silva, Angew. Chem. Int. Ed. 2016, 55, 768.

23 A. P. de Silva, H. Q. N. Gunaratne and C. P. McCoy, J. Am. Chem. Soc. 1997, 119, 7891.

24 R. A. Bissell, A. P. de Silva, H. Q. N. Gunaratne, P. L. M. Lynch, G. E. M. Maguire and K. R. A. S. Sandanayake, Chem. Soc. Rev. 1992, 21, 187; A. P. de Silva, T. P. Vance, M. E. S. West and G. D. Wright, Org. Biomol. Chem. 2008, 6, 2468.

25 M. J. Kamlet, J. -L. M. Abboud and R. W. Taft, Progr. Phys. Org. Chem. 1981, 13, 485.

26 E. M. Kosower, Acc. Chem. Res. 1982, 15, 259; G. Weber and D. J. R. Laurence, Biochem. J. 1954, 31, 56.

27 A. P. de Silva, Molecular Logic-based Computation, Royal Society of Chemistry, Cambridge, 2013; B. Daly, J. Ling, V. A. D. Silverson and A. P. de Silva, Chem. Commun. 2015, 51, 8403.

28 Y. Hatanaka, Chem. Pharm. Bull. 2015, 63, 1.

29 K. Yoshida, T. Mori, S. Watanabe, H. Kawai, T. Nagamura, J. Chem. Soc. Perkin Trans. 2 1999, 393; H. Kawai, T. Nagamura, T. Mori, K. Yoshida, J. Phys. Chem. A 1999, 103, 660; P. Batat, G. Vives, R. Bofinger, R. W. Chang, B. Kauffmann, R. Oda, G. Jonusauskas and N. D. McClenaghan, Photochem. Photobiol. Sci. 2012, 11, 1666.

30 J. B. Birks, Photophysics of Aromatic Molecules, Wiley, London, 1970.

31 S. R. Stoitsova, R. N. Boteva and R. J. Doyle, Biochim. Biophys. Acta, 2003, 1619, 213. 


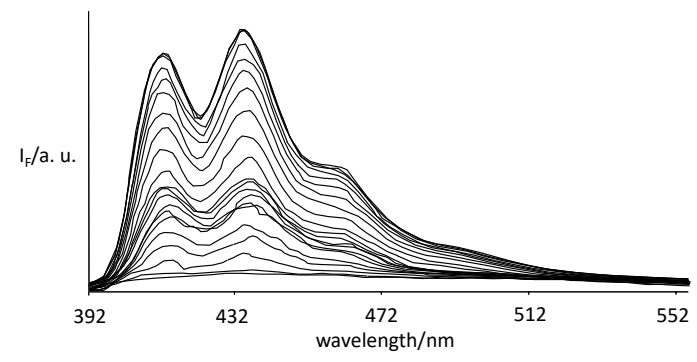

Figure 1. Fluorescence emission spectra for $10^{-5} \mathrm{M} 1$ (excited at $380 \mathrm{~nm}$ ) in aqueous phosphate buffer ( $\mathrm{pH} 7.2,0.1 \mathrm{M}$ ) solution in the presence of avidin at $0.0,0.3,0.6,0.9,1.2,1.5,1.8,2.1,2.4,2.7,3.0,4.2,6.3,8.4,10.0,13.0,15.0,17.0,19.0,23.0$ and $25.0 \mu \mathrm{M}$ concentrations (in order of increasing intensity at $436 \mathrm{~nm}$ ).

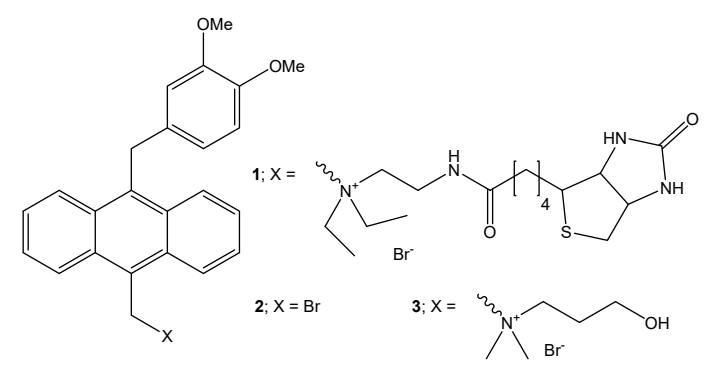

Scheme 1. Structures of sensors $\mathbf{1}$ and $\mathbf{3}$ and intermediate $\mathbf{2}$.

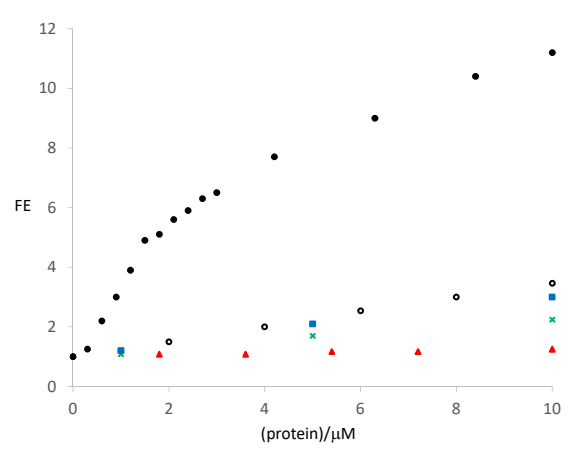

Figure 2. Protein-induced fluorescence intensity $\left(\mathrm{I}_{\mathrm{F}}\right)$ enhancements $(\mathrm{FE})$ as a function of protein concentration, according to the conditions given in Figure 1; 1-avidin (filled circles), 1-concanavalin A (open circles), 1-BSA (blue squares), 3-BSA (green crosses) and 3-avidin (red triangles).

Table 1. Fluorescence and binding parameters for sensor-protein pairs. ${ }^{a}$

\begin{tabular}{|l|l|l|l|l|l|}
\hline Sensor & Protein & $\mathrm{FE}_{l i m}{ }^{\mathrm{b}}$ & $\mathrm{FE}_{10 \mu \mathrm{M}}{ }^{\mathrm{c}}$ & $\phi_{\mathrm{F}}{ }^{\mathrm{d}}$ & $\log \beta^{\mathrm{e}}$ \\
\hline $\mathbf{1}$ & avidin & 15.1 & 11.2 & 0.094 & 5.1 \\
\hline $\mathbf{1}$ & con A & $--^{\mathrm{f}}$ & 3.5 & $-\mathrm{g}$ & $-\mathrm{g}$ \\
\hline $\mathbf{1}$ & BSA & $-^{\mathrm{f}}$ & 3.0 & $-\mathrm{g}$ & $-\mathrm{g}$ \\
\hline $\mathbf{3}$ & avidin & $-^{\mathrm{f}}$ & 1.25 & $-\mathrm{g}$ & $-\mathrm{g}$ \\
\hline $\mathbf{3}$ & BSA & 16.0 & 2.2 & 0.068 & 4.2 \\
\hline
\end{tabular}

a. Under conditions given in Fig. 1. b. limiting intensity is observable by maximization and levelling-off of the intensity as the concentration of the protein is increased as far as practicable. $\phi_{\mathrm{F}}=0.0063$ for $\mathbf{1}$ and 0.0043 for $\mathbf{3}$. c. at $10 \mu \mathrm{M}$ protein. $\mathrm{d}$. fluorescence quantum yield (reference: 9,10-diphenylanthracene in aerated ethanol). ${ }^{30}$ e. obtained from equation, $\log \left[\left(I_{\mathrm{Fmax}}\right.\right.$ $\left.\left.-I_{F}\right) /\left(I_{F}-I_{F m i n}\right)\right]=p S e n s o r+\log \beta,{ }^{31}$ by varying the concentration of sensor while holding the concentrations of avidin and BSA constant at $20 \mu \mathrm{M}$ and $200 \mu \mathrm{M}$ respectively. This necessitated the use of front-face observation at higher sensor 
concentrations. f. limiting intensity not achieved within experimental range. g. not calculated since limiting intensity is not achieved.

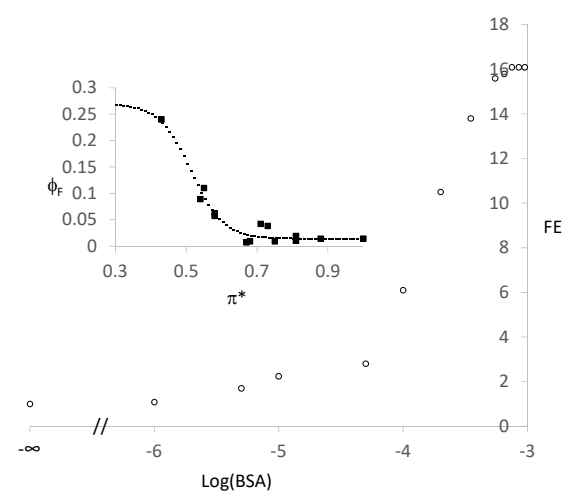

Figure 3. Fluorescence intensity enhancements (FE) of $\mathbf{3}$ induced by various concentrations of BSA (M units), according to the conditions given in Fig. 1. Inset: Fluorescence quantum yield $\left(\phi_{\mathrm{F}}\right)$ of $\mathbf{3}$ as a function of solvent dipolarity $\left(\pi^{*}\right)$. Experimental data (squares, see ESI) and data calculated (dashes) according to equation, $\log \left[\left(\phi_{F \max }-\phi_{F}\right) /\left(\phi_{F}-\phi_{F m i n}\right)\right]=B \pi^{*}+A$, where $\pi^{*}$ is the Kamlet-Taft dipolarity, ${ }^{25}$ and $A$ and $B$ are constants, with $\phi_{F \max }=0.27, \phi_{F \min }=0.014, B=9.6$ and $A=-4.9$ for best fit to the experimental data.
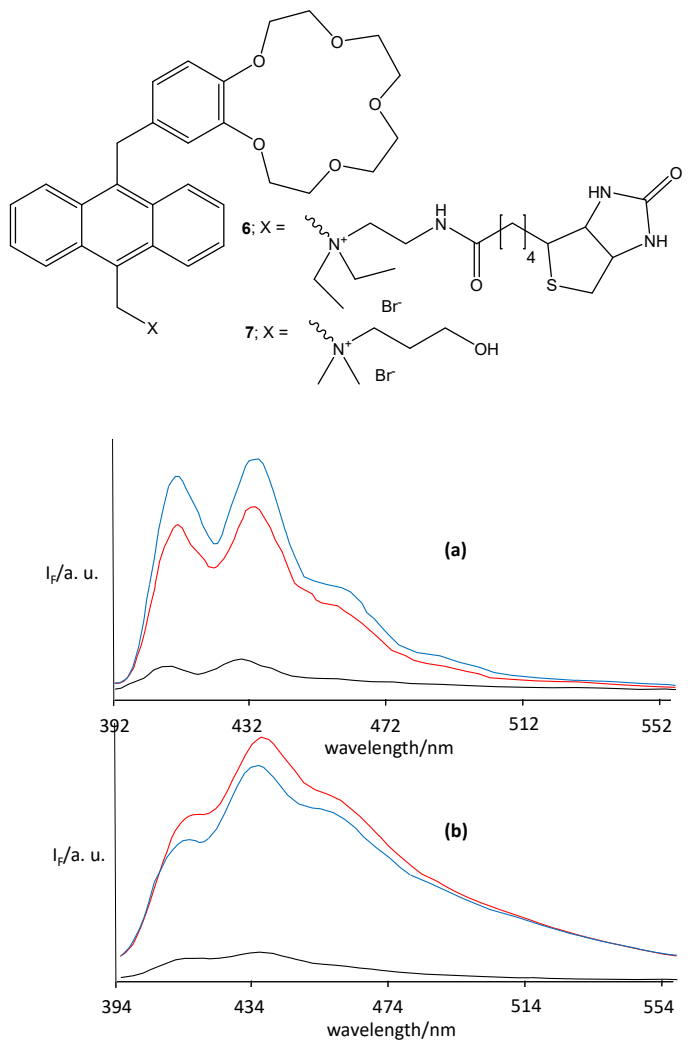

Figure 4. Structures of sensors $\mathbf{6}$ and $\mathbf{7}$ and their fluorescence spectra (a and b respectively) alone (black), with added $20 \mu \mathrm{M}$ avidin or $1.2 \mathrm{mM} \mathrm{BSA}$ (blue) and with added $1 \mathrm{M} \mathrm{NaCl}$ (red). 
